\title{
Luomuraakamaidon rasvahappokoostumuksen seuranta Etelä-Savossa
}

\author{
Niina Saastamoinen ${ }^{1}$, Seija Jaakkola ${ }^{2}$ ja Aila Vanhatalo ${ }^{2}$ \\ ${ }^{1}$ ProAgria Etelä-Savo ry, Mikonkatu 5, 50100 Mikkeli, etunimi.sukunimi@ proagria.fi \\ ${ }^{2}$ Helsingin yliopisto, Maataloustieteiden laitos, Helsingin yliopisto, PL 28, 00014 Helsingin yliopisto, \\ etunimi.sukunimi@helsinki.fi
}

\section{Tiivistelmä}

Luomulypsylehmien ruokintaan liittyy tekijöitä, joiden on useissa koti- ja ulkomaisissa tutkimuksissa todettu vaikuttavan edullisesti maidon rasvahappokoostumukseen. Näitä ovat muun muassa karkearehuvaltainen ruokinta, laiduntaminen, apilaa sisältävien karkearehujen käyttö sekä rasvaa sisältävän rypsipuristeen käyttö. Typensitojakasvina tunnettu puna-apila on erityisen tärkeä säilörehun raaka-aine luomumaitotiloilla, joten sen säännöllisen käytön ruokinnassa voidaan olettaa vaikuttavan positiivisesti myös tuotetun raakamaidon rasvahappokoostumukseen.

Puna-apila on tutkimuksissa lisännyt erityisesti monityydyttymättömän $\alpha$-linoleenihapon ja vähentänyt tyydyttyneiden keskipitkäketjuisten rasvahappojen, erityisesti palmitiinihapon osuutta maitorasvassa. Käytännössä puna-apilan osuus luomutilojen säilörehuissa kuitenkin vaihtelee vuodesta ja korjuuajankohdasta sekä muista tilatason tekijöistä johtuen, eikä tiedetä kuinka tämä vaikuttaa maidon rasvahappokoostumukseen. Tämän seurantatutkimuksen tavoitteena oli selvittää luomuraakamaidon rasvahappokoostumuksen vaihtelua kahden vuoden ajalta.

Osana Luomumaito - luonnostaan terveellistä -hanketta toteutetussa seurantatutkimuksessa oli vuosien 2008 - 2010 aikana mukana 9 - 10 eteläsavolaista luomumaitotilaa, joilta kerättiin $3-5$ viikon välein raakamaitonäytteet tankkimaidosta rasvahappomäärityksiä varten. Rasvahappomääritys tehtiin MTT:n laboratoriossa standardimenetelmin. Maitonäytteiden oton ajankohtana syötössä olleista säilörehuista määritettiin kemiallinen koostumus ja rehuarvot (ARTTURI-analyysi). Tiloilta kysyttiin myös tiedot käytettyjen väkirehujen määrästä ja laadusta vastaavalta ajalta.

Säilörehunäytteistä määritetyn kalsiumpitoisuuden perusteella tilalla tuotetun säilörehun apilapitoisuus vaihteli suuresti sekä tilojen sisällä että niiden välillä. Puna-apilapitoisen rehun käyttö heijastui maitorasvan keskimääräiseen koostumukseen jonkin verran kohonneena $\alpha$-linoleenihapon pitoisuutena, mutta vaihtelu rasvahappojen pitoisuuksissa sekä tilojen välillä että saman tilan maitonäytteissä eri näytteenottokertojen välillä oli melko suurta. Laidun- ja sisäruokintakauden välinen ero maidon rasvahappokoostumuksessa oli selvästi havaittavissa maitorasvan pehmenemisenä laidunkaudella. Tyydyttyneiden rasvahappojen pitoisuus väheni keskimäärin noin $5 \%$-yksikköä ja kerta- ja monityydyttymättömien rasvahappojen, muun muassa konjugoidun linolihapon ja $\alpha$-linoleenihapon, pitoisuudet lisääntyivät laidunkauden aikana vastaavasti.

Asiasanat: luomuruokinta, säilörehu, tankkimaito, rasvahappokoostumus 


\section{Johdanto}

Luomulypsylehmien ruokintaan liittyy sekä luontaisesti että tuotantoehtojen puitteissa (Evira 2009) tekijöitä, joiden on useissa koti- ja ulkomaisissa tutkimuksissa todettu vaikuttavan edullisesti maidon rasvahappokoostumukseen. Näitä ovat $\mathrm{mm}$. karkearehuvaltainen ruokinta, laiduntaminen, apilaa sisältävien karkearehujen käyttö sekä rasvaa sisältävän rypsipuristeen käyttö.

Typensitojakasvina tunnettu puna-apila on erityisen tärkeä säilörehun raaka-aine luomumaitotiloilla, joten sen säännöllinen käyttö ruokinnassa mahdollisesti parantaa tuotetun raakamaidon rasvahappokoostumusta. Puna-apilasäilörehu on tutkimuksissa lisännyt erityisesti monityydyttymättömän $\alpha$-linoleenihapon (C18:3 n-3) ja vähentänyt tyydyttyneiden keskipitkäketjuisten rasvahappojen, muun muassa palmitiinihapon (C16:0) osuutta maitorasvassa (Vanhatalo ym. 2008). Puna-apilan osuus säilörehussa tilatasolla kuitenkin vaihtelee vuodesta (Sairanen ym. 2010) ja korjuuajankohdasta sekä muista tilatekijöistä johtuen (Riesinger ym. 2008), eikä tiedetä missä määrin tämä vaikuttaa tuotetun maidon rasvahappokoostumukseen.

Tilatasolla säilörehujen apilapitoisuutta voidaan arvioida suppeaan kivennäisanalyysiin (ARTTURI-analyysi) kuuluvan kalsiumpitoisuuden perusteella (Rinne ym. 2008). Eteläsavolaisten luomumaitotilojen säilörehujen apilapitoisuudessa on kalsiumpitoisuuden perusteella todettu suurta vaihtelua (Nykänen 2009, julkaisematon). Luomutilojen rehujen apilapitoisuuksia ja tuotetun maidon rasvahappokoostumusta ei ole kuitenkaan seurattu systemaattisesti. Tämän tutkimuksen tavoitteena oli selvittää luomuraakamaidon rasvahappokoostumuksen vaihtelua kahden vuoden ajalta eteläsavolaisilla luomutiloilla. Tämä seurantatutkimus on osa ProAgria Etelä-Savon hallinnoimaa Luomumaito - luonnostaan terveellistä -hanketta, jota rahoittavat muun muassa Euroopan maaseudun kehittämisen maatalousrahasto: Eurooppa investoi maaseutualueisiin, Etelä-Savon ELY-keskus ja Juvan Luomu Oy.

\section{Aineisto ja menetelmät}

Seurantatutkimuksessa mukana olleilta luomumaitotiloilta (2008-2009 10 kpl, 2009-2010 9 kpl) kerättiin maitonäytteet pakkaseen rasvahappomääritystä varten 3-5 viikon välein. Maitonäytteiden rasvahappomääritys tehtiin MTT:n laboratoriossa. Rasvahappojen metylointi tehtiin Na-metoksidilla ja näytteet analysoitiin kaasukromatografisesti (GC-FID). Rasvahapot eroteltiin 100 m:n kapillaarikolonnissa (CP Sil 88) ja ne tunnistettiin vertaamalla niiden retentioaikoja standardien (75 eri rasvahappoa) retentioaikoihin. Pitoisuuksien määrityksessä käytettiin apuna Nu Chek Prep 606-standardilla tehtyä kalibrointitaulukkoa. Maitonäytteiden oton ajankohtana syötössä olleista säilörehuista määritettiin Valion laboratoriossa kemiallinen koostumus sisältäen kalsiumin, fosforin ja kaliumin pitoisuudet sekä rehuarvot (ARTTURI-analyysi). Tiloilta kysyttiin myös tiedot käytettyjen väkirehujen määrästä ja laadusta vastaavalta ajalta.

\section{Tulokset ja tulosten tarkastelu}

Rehuarvomäärityksessä mukana olleita karkearehunäytteitä kerättiin yhteensä $182 \mathrm{kpl}$, ja niiden koostumustiedot on esitetty taulukossa 1 . Seurannassa mukana olleilla luomutiloilla väkirehuista yleisim-

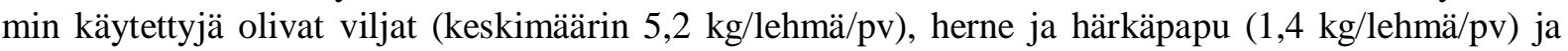
rypsipuriste $(1,1 \mathrm{~kg} / \mathrm{lehmä/pv})$. Muiden väkirehujen (kaupalliset täydennysrehut, elintarviketeollisuuden sivutuotteet) osuus oli hyvin vähäinen. Rasvahappomäärityksen läpikäyneistä maitonäytteistä yhteensä $224 \mathrm{kpl}$ oli mukana kaksivuotisessa seurannassa. Toisena seurantavuonna (2009-2010) maitonäytemääriä $(98 \mathrm{kpl})$ verottivat ongelmat näytteiden keruussa, pilaantuminen tilavarastoinnissa sekä näytteiden puutteelliset tunnistusmerkinnät. Maidon keskeiset rasvahapot seurantavuosittain on esitetty taulukossa 2.

Kalsiumpitoisuuden perusteella säilörehujen apilapitoisuus oli alle $40 \%$ (1. vuosi 31,5 \%, 2. vuosi 36,0 \%) rehun kuiva-aineesta. Kaikkien Artturi-analyysiin tulevien, apilapitoisiksi lähtötiedoissa merkittyjen säilörehujen apilapitoisuus on noin 30 \% (Hellämäki 2010, henkilökohtainen tiedonanto). Osa tämän seurannan karkearehunäytteistä oli otettu laitumista (ei määritetty kalsiumpitoisuutta) ja osa säilörehuista sisälsi tilojen kertoman mukaan yksivuotisia rehukasveja (viljoja ja yksivuotisia palkokasveja), joten kaikki apilapitoisuuden määrittämistä varten kerätyt kalsiumarvot eivät välttämättä olleet apilapitoisista säilörehuista peräisin. Seurantatutkimuksessa mukana olleiden tilojen apilapitoisiksi tiedettyjen säilörehujen kalsiumpitoisuuksien perusteella on kuitenkin jo aiemmin saatu samansuuntaisia arvoja (Nykänen 2009, julkaisematon). 
Taulukko 1. Karkearehujen* keskimääräinen koostumus ja rehuarvot (g/kg kuiva-ainetta, jos ei muuta mainittu) seurantavuosien aikana.

\begin{tabular}{|c|c|c|c|c|c|c|}
\hline & $\mathrm{n}$ & Keski-arvo & Mediaani & Minimi & Maksimi & $\begin{array}{l}\text { Keski- } \\
\text { hajonta }\end{array}$ \\
\hline \multicolumn{7}{|l|}{ Vuosi 1} \\
\hline Kuiva-aine, g/kg & 96 & 302 & 285 & 125 & 698 & 105,7 \\
\hline D-arvo & 96 & 666 & 670 & 590 & 740 & 36,7 \\
\hline Raakavalkuainen & 96 & 133 & 131 & 72 & 273 & 30,7 \\
\hline Kuitu (NDF) & 96 & 485 & 476 & 398 & 637 & 55,2 \\
\hline $\mathrm{ry} / \mathrm{kg} \mathrm{ka}$ & 96 & 0,91 & 0,92 & 0,81 & 1,02 & 0,051 \\
\hline $\mathrm{ME} \mathrm{MJ/kg} \mathrm{ka}$ & 96 & 10,6 & 10,8 & 9,5 & 11,9 & 0,60 \\
\hline OIV & 96 & 82,4 & 82,5 & 72,0 & 96,0 & 4,26 \\
\hline PVT & 96 & $-7,9$ & $-10,0$ & $-56,0$ & 107,0 & 26,11 \\
\hline Syönti-indeksi & 87 & 108 & 110 & 87 & 120 & 10,2 \\
\hline $\mathrm{pH}$ & 87 & 4,11 & 4,00 & 3,70 & 5,10 & 0,340 \\
\hline Sokeri & 87 & 65,0 & 44,0 & 4,0 & 288,0 & 54,26 \\
\hline Maito- ja muurahaishappo & 87 & 61,5 & 69,0 & 0,0 & 99,0 & 27,44 \\
\hline Haihtuvat rasvahapot & 87 & 18,1 & 17,0 & 0,0 & 69,0 & 13,30 \\
\hline Ammoniakki-N, g/kg N & 87 & 29,5 & 20,0 & 0,0 & 190,0 & 34,37 \\
\hline Liukoinen $\mathrm{N}, \mathrm{g} / \mathrm{kg} \mathrm{N}$ & 87 & 389 & 370 & 100 & 950 & 145,9 \\
\hline $\mathrm{Ca}$ & 84 & 8,43 & 8,45 & 3,20 & 14,00 & 2,645 \\
\hline $\mathrm{P}$ & 84 & 2,39 & 2,30 & 1,60 & 3,50 & 0,389 \\
\hline $\mathrm{K}$ & 84 & 21,4 & 20,4 & 7,0 & 39,4 & 5,42 \\
\hline \multicolumn{7}{|l|}{ Vuosi 2} \\
\hline Kuiva-aine, g/kg & 86 & 300 & 287 & 128 & 729 & 92,9 \\
\hline D-arvo & 86 & 657 & 660 & 570 & 740 & 35,0 \\
\hline Raakavalkuainen & 86 & 136 & 133 & 73 & 250 & 29,0 \\
\hline Kuitu (NDF) & 86 & 501 & 496 & 394 & 1200 & 88,9 \\
\hline $\mathrm{ry} / \mathrm{kg} \mathrm{ka}$ & 86 & 0,90 & 0,90 & 0,77 & 1,02 & 0,049 \\
\hline $\mathrm{ME} \mathrm{MJ/kg} \mathrm{ka}$ & 86 & 10,5 & 10,5 & 9,0 & 11,9 & 0,57 \\
\hline OIV & 86 & 82,7 & 83,0 & 69,0 & 100,0 & 5,59 \\
\hline PVT & 86 & 13,1 & 9,0 & $-31,0$ & 82,0 & 23,06 \\
\hline Syönti-indeksi & 76 & 108 & 108 & 77 & 120 & 8,9 \\
\hline $\mathrm{pH}$ & 76 & 4,02 & 4,00 & 3,50 & 5,30 & 0,287 \\
\hline Sokeri & 86 & 53,4 & 43,0 & 0,0 & 256,0 & 42,27 \\
\hline Maito- ja muurahaishappo & 76 & 66,1 & 70,5 & 0,0 & 120,0 & 24,42 \\
\hline Haihtuvat rasvahapot & 76 & 17,9 & 16,5 & 0,0 & 50,0 & 9,77 \\
\hline Ammoniakki-N, g/kg N & 76 & 24,7 & 20,0 & 0,0 & 70,0 & 16,53 \\
\hline Liukoinen $\mathrm{N}, \mathrm{g} / \mathrm{kg} \mathrm{N}$ & 76 & 389 & 390 & 60 & 640 & 103,8 \\
\hline $\mathrm{Ca}$ & 74 & 9,24 & 8,95 & 3,10 & 16,40 & 2,728 \\
\hline $\mathrm{P}$ & 74 & 2,46 & 2,40 & 1,90 & 3,70 & 0,361 \\
\hline $\mathrm{K}$ & 74 & 22,4 & 22,0 & 10,0 & 37,6 & 4,98 \\
\hline
\end{tabular}

* Karkearehu oli pääsääntöisesti säilörehua. Joidenkin tilojen näytteissä oli satunnaisesti mukana myös laidunnäyte.

Useissa tutkimuksissa on todettu yhteys säilörehun puna-apilapitoisuuden ja maitorasvan kohonneen $\alpha$-linoleenihappopitoisuuden välillä (Vanhatalo ym. 2008). Tässä seurantatutkimuksessa puna-apilan osuus säilörehusta oli melko pieni ja vaihtelua esiintyi paljon. Nyt saadut tulokset monityydyttymättömien rasvahappojen osuuden lisäämiseksi ja tyydyttyneiden rasvahappojen osuuden vähentämiseksi maidossa ovat toivotun suuntaisia, mutta muun muassa $\alpha$-linoleenihapon keskimääräinen pitoisuus on puna-apilan puhdaskasvustotutkimuksiin (Vanhatalo ym. 2007, Vanhatalo ym. 2008) verrattuna pienempi (taulukko 2, kuviot 1 - 3). Mainituissa tutkimuksissa puna-apilasäilörehuruokinnalla tuotetun maidon $\alpha$-linoleenihapon pitoisuus vaihteli $0,67-1,34 \mathrm{~g} / 100 \mathrm{~g}$ rasvahappoja ja kontrollisäilörehuruokinnalla (nurmiheinä) tuotetun maidon vastaava pitoisuus $0,37-0,48 \mathrm{~g} / 100 \mathrm{~g}$ rasvahappoja. 
Taulukko 2. Tankkimaidon keskimääräinen rasvahappokoostumus (g/100 g rasvahappoja) kahden seurantavuoden aikana.

\begin{tabular}{|c|c|c|c|c|c|c|}
\hline Rasvahappo & $\mathrm{n}$ & $\begin{array}{c}\text { Keski- } \\
\text { arvo }\end{array}$ & Mediaani & Minimi & Maksimi & $\begin{array}{l}\text { Keski- } \\
\text { hajonta }\end{array}$ \\
\hline \multicolumn{7}{|l|}{ Vuosi 1} \\
\hline $\mathrm{C} 4: 0$ & 126 & 3,30 & 3,29 & 2,89 & 3,74 & 0,156 \\
\hline C6:0 & 126 & 2,01 & 2,03 & 1,54 & 2,33 & 0,143 \\
\hline $\mathrm{C} 8: 0$ & 126 & 1,21 & 1,23 & 0,84 & 1,55 & 0,131 \\
\hline C10:0 & 126 & 2,76 & 2,80 & 1,76 & 3,97 & 0,402 \\
\hline C12:0 & 126 & 3,27 & 3,30 & 2,01 & 4,91 & 0,523 \\
\hline $\mathrm{C} 14: 0$ & 126 & 11,1 & 11,3 & 8,13 & 13,2 & 1,049 \\
\hline C16:0 & 126 & 28,6 & 28,1 & 22,3 & 36,8 & 3,23 \\
\hline C18:0 & 126 & 11,6 & 11,6 & 8,27 & 14,9 & 1,525 \\
\hline C18:1 cis yhteensä & 126 & 21,5 & 21,1 & 15,9 & 30,5 & 2,98 \\
\hline C18:1 trans yhteensä & 126 & 2,37 & 2,25 & 1,32 & 4,73 & 0,659 \\
\hline $\mathrm{C} 18: 2$ cis 9, trans 11 & 126 & 0,53 & 0,50 & 0,29 & 1,08 & 0,179 \\
\hline C18:2 (n-6) & 96 & 1,38 & 1,37 & 1,07 & 2,05 & 0,194 \\
\hline $\mathrm{C} 18: 3(\mathrm{n}-3)$ & 126 & 0,59 & 0,58 & 0,33 & 0,98 & 0,142 \\
\hline C4:0-C14:0 (de novo) & 126 & 24,0 & 24,4 & 17,6 & 29,7 & 2,20 \\
\hline Tyydyttyneet & 126 & 67,4 & 67,9 & 58,1 & 74,6 & 3,69 \\
\hline Kertatyydyttymättömät & 126 & 28,9 & 28,3 & 22,1 & 38,4 & 3,57 \\
\hline Monityydyttymättömät & 126 & 3,36 & 3,36 & 1,70 & 4,71 & 0,554 \\
\hline \multicolumn{7}{|l|}{ Vuosi 2} \\
\hline $\mathrm{C} 4: 0$ & 98 & 3,97 & 3,97 & 3,50 & 4,45 & 0,219 \\
\hline C6:0 & 98 & 2,35 & 2,40 & 1,77 & 2,66 & 0,197 \\
\hline $\mathrm{C} 8: 0$ & 98 & 1,36 & 1,39 & 0,89 & 1,66 & 0,165 \\
\hline C10:0 & 98 & 2,94 & 2,96 & 1,80 & 3,89 & 0,451 \\
\hline $\mathrm{C} 12: 0$ & 98 & 3,33 & 3,35 & 1,96 & 4,39 & 0,535 \\
\hline C14:0 & 98 & 11,1 & 11,4 & 7,42 & 12,8 & 1,092 \\
\hline C16:0 & 98 & 26,8 & 26,6 & 19,9 & 34,5 & 3,06 \\
\hline C18:0 & 98 & 11,8 & 11,5 & 8,31 & 15,6 & 1,590 \\
\hline C18:1 cis yhteensä & 98 & 21,6 & 20,9 & 16,7 & 29,9 & 2,92 \\
\hline C18:1 trans yhteensä & 98 & 2,68 & 2,49 & 1,52 & 4,77 & 0,687 \\
\hline C18:2 cis 9, trans 11 & 98 & 0,58 & 0,55 & 0,34 & 1,03 & 0,165 \\
\hline C18:2 (n-6) & 98 & 1,36 & 1,35 & 0,93 & 1,97 & 0,192 \\
\hline $\mathrm{C} 18: 3(\mathrm{n}-3)$ & 98 & 0,61 & 0,62 & 0,26 & 1,00 & 0,133 \\
\hline C4:0-C14:0 (de novo) & 98 & 25,3 & 26,0 & 18,0 & 29,3 & 2,46 \\
\hline Tyydyttyneet & 98 & 67,2 & 67,7 & 57,6 & 74,5 & 3,81 \\
\hline Kertatyydyttymättömät & 98 & 28,8 & 28,2 & 22,6 & 37,6 & 3,42 \\
\hline Monityydyttymättömät & 98 & 3,86 & 3,89 & 2,71 & 5,01 & 0,532 \\
\hline
\end{tabular}

Aineistossa ei todettu selkeää yhteyttä yksittäisten säilörehunäytteiden kalsiumpitoisuuden (apilapitoisuuden) ja vastaavien maitonäytteiden $\alpha$-linoleenihappopitoisuuden välillä. Tulos selittynee lähtötietojen puutteilla. Kokonaan puuttuvat rehunäytteet ja maitonäytteiden tunnistusmerkintöjenpuutteellisuudet ovat varmasti osaltaan olleet vaikuttamassa, mutta tilatasolla syöttöön tuleva säilörehuerä saattaa vaihdella jopa saman päivän eri rehunjakokerroilla. Säilörehunäytteiden parempi edustavuus aineistossa olisi todennäköisesti korjannut tilannetta.

Tuoreen ruohon (laidunnus) on tutkimuksissa todettu lisäävän konjugoidun linolihapon (cis9, trans11 C18:2) osuutta maitorasvassa (De Wit ym. 2008). Vaikka tässä seurannassa mukana olevien luomutilojen laidunnuskäytännöissä on paljon vaihtelua, laidunkauden ero sisäruokintakauteen verrattuna on selvästi nähtävissä (kuvio 2).

Väkirehujen kokonaiskäyttömäärällä ei havaittu yhteyttä C18:3 (n-3) tai cis9, trans11 C18:2 -rasvahappojen pitoisuuksiin maidossa. Toisaalta väkirehujen koostumuksen vaikutusta maidon rasvahappokoostumukseen oli tästä aineistosta vaikea päätellä. Luultavasti hankintahinnaltaan arvokkaiden herneen ja härkäpavun sekä rypsipuristeen käyttömäärät ovat yhteydessä myös tilan mahdollisuuteen panostaa peltojen kasvukuntoon ja puna-apilan menestymiseen. 


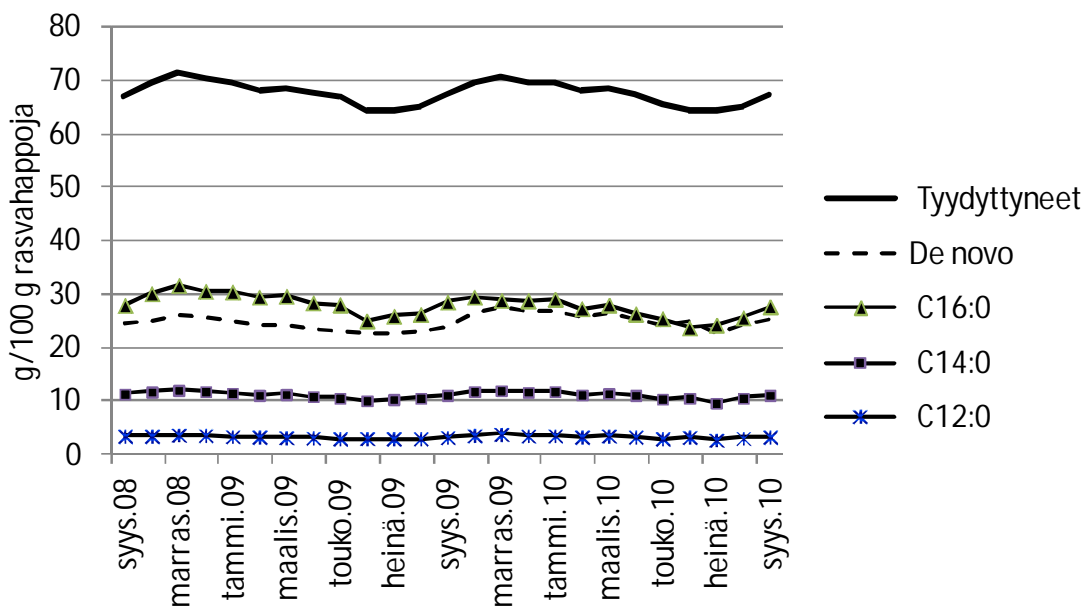

Kuvio 1. Tankkimaidon tyydyttyneiden, de novo- synteesin (C4:0-C14:0) ja yksittäisten rasvahappojen (C16:0, C14:0 ja C12:0) keskimääräinen pitoisuus maitorasvassa seurantakauden aikana

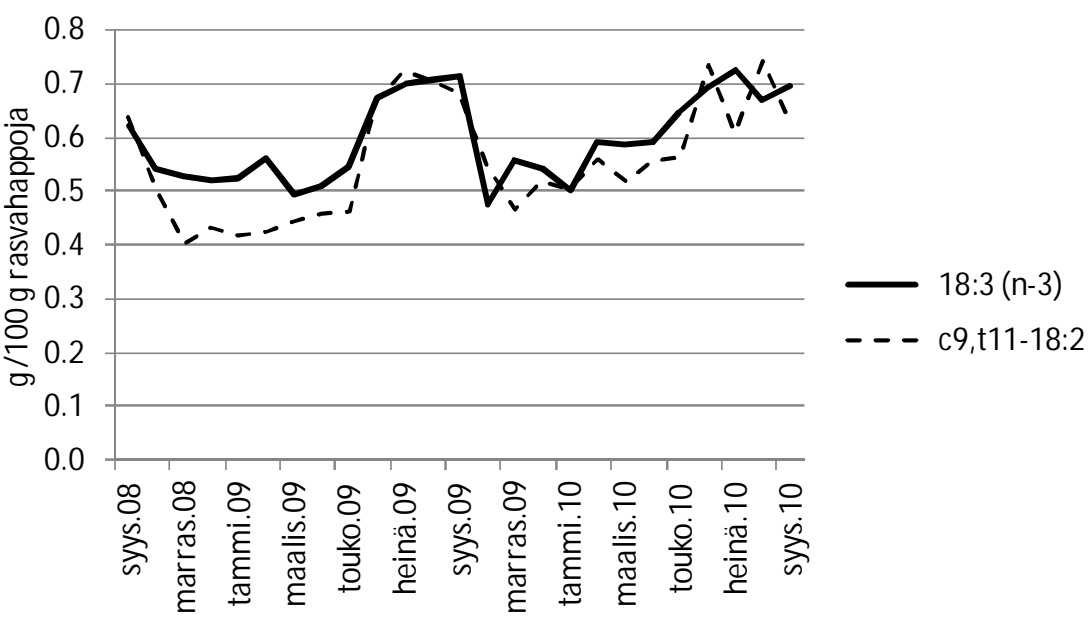

Kuvio 2. Tankkimaidon $\alpha$-linoleenihapon, C18:3 (n-3), ja konjugoidun linolihapon (cis-9, trans-11 C18:2) keskimääräinen pitoisuus maitorasvassa seurantakauden aikana

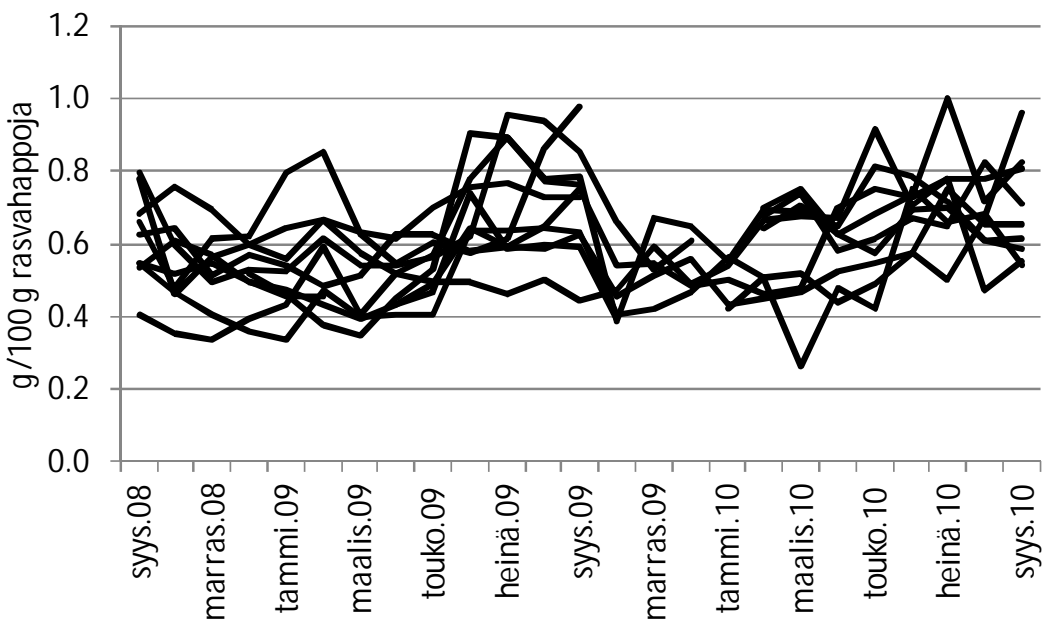

Kuvio 3. Yksittäisten tilojen tankkimaidon $\alpha$-linoleenihapon, C18:3 (n-3), pitoisuus maitorasvassa seurantakauden aikana. 


\section{Johtopäätökset}

Säilörehunäytteistä määritetyn kalsiumpitoisuuden perusteella seurantatiloilla tuotetun säilörehun apilapitoisuus vaihteli suuresti sekä tilojen sisällä että niiden välillä keskimääräisen apilapitoisuuden ollessa alle $40 \%$ rehun kuiva-aineesta.

Puna-apilapitoisen rehun käyttö heijastui maitorasvan keskimääräiseen koostumukseen jonkin verran kohonneena $\alpha$-linoleenihapon pitoisuutena, mutta vaihtelu rasvahappojen pitoisuuksissa sekä tilojen välillä että saman tilan maitonäytteissä eri näytteenottokertojen välillä oli melko suurta. Laidun- ja sisäruokintakauden välinen ero maidon rasvahappokoostumuksessa oli selvästi havaittavissa maitorasvan pehmenemisenä laidunkaudella. Väkirehujen kokonaiskäyttömäärällä ei havaittu olevan yhteyttä maidon $\alpha$-linoleenihapon tai konjugoidun linolihapon pitoisuuksiin.

Tämän kaksivuotisen tilaseurannan perusteella puna-apilasäilörehun ja laitumen käyttö luomuruokinnassa näkyy luomuraakamaidon rasvahappokoostumuksessa. Luomuruokinnan edulliset vaikutukset jäävät kuitenkin ajoittaisiksi, jos puna-apilan osuus tilasäilörehussa jää pieneksi tai se vaihtelee suuresti tuotantokauden aikana.

\section{Kirjallisuus}

Artturi. www.agronet.fi/artturi

De Wit, J. \& de Vries, A. 2008. Feed composition and strategies to improve poly-unsaturated fatty acid levels in organic cow milk. $16^{\text {th }}$ IFOAM Organic World Congress, Modena, Italy, June 16-20, 2008. www.louisbolk.org/downloads/2175.pdf

Elintarviketurvallisuusvirasto Evira. Eviran ohje 18217/2. Käyttöönotto 1.1.2001, 2.painos 1.1.2010. Luonnonmukaisen tuotannon ohjeet 2. Eläintuotanto. 2.painos. Julkaisu on saatavilla Eviran internetsivuilta osoitteesta www.evira.fi

Riesinger, P. \& Herzon, I. 2008. Variability of herbage production in mixed leys as related to ley age and environmental factors: a farm survey. Agricultural and Food Science. 17: 394-412.

Rinne, M. , Nykänen, A., Kemppainen, J., Nyholm, L. \& Nousiainen, J. 2008. Nurmikasvuston puna-apilapitoisuuden voi ennustaa kalsiumpitoisuudesta. Julkaisussa: Maataloustieteen Päivät 2008 [verkkojulkaisu]. Suomen Maataloustieteellisen Seuran tiedotteita no 23. Toim. Anneli Hopponen. Viitattu 11.11.2011. Julkaistu 9.1.2008. Saatavilla Internetissä: http://www.smts.fi (Nurmikasvuston puna-apilapitoisuuden voi ennustaa puna-apilapitoisuudesta). ISBN 978-951-9041-51-3.

Sairanen, A. \& Juutinen E. 2010. Niittoajan ja niittokerran sekä väkirehun valkuaispitoisuuden vaikutus maitotuotokseen ja syöntiin lypsylehmillä syötettäessä puna-apilasäilörehua.

MAA103(KARPE). 21 p. (Loppuraportti).

Vanhatalo, A., Kuoppala, K., Toivonen, V. \& Shingfield, K. J. 2007. Effects of forage species and stage of maturity on bovine milk fatty acid composition. European Journal of Lipid Science and Technology 109, 8: 856-867.

Vanhatalo, A., Pursiainen, P. \& Tuori, M. 2008. Puna-apilarehun korjuuajan vaikutus maidon rasvahappokoostumukseen. Julkaisussa: Maataloustieteen Päivät 2008 [verkkojulkaisu]. Suomen Maataloustieteellisen Seuran tiedotteita no 23. Toim. Anneli Hopponen. Viitattu 11.11.2011. Julkaistu 9.1.2008. Saatavilla Internetissä: http://www.smts.fi (Puna-apilarehun korjuuajan vaikutus maidon rasvahappokoostumukseen). ISBN 978-951-9041-51-3. 